\title{
GMR
}

\section{Effect of polymorphisms in interleukin-18 gene on the susceptibility to coronary artery disease in a Chinese population}

\author{
J.B. Ma ${ }^{1}$ L. Chen ${ }^{2}$, B. Gao ${ }^{3}$ and J. Xu${ }^{4}$ \\ ${ }^{1}$ Department of Cardiovascular Diseases, First Hospital of Yulin, Yulin, \\ Shaanxi, China \\ ${ }^{2}$ Department of Cardiology, People's Hospital of Tongchuan, Tongchuan, \\ Shaanxi, China \\ ${ }^{3}$ Department of Cardio-Cerebrovascular Diseases, \\ Affiliated Hospital of Yanan University, Yanan, Shaanxi, China \\ ${ }^{4}$ Health Team, People's Armed Police Detachment of Tongchuan, Tongchuan, \\ Shaanxi, China \\ Corresponding author: B. Gao \\ E-mail: gaoboyn@163.com \\ Genet. Mol. Res. 15 (4): gmr15048708 \\ Received April 12, 2016 \\ Accepted June 22, 2016 \\ Published October 24, 2016 \\ DOI http://dx.doi.org/10.4238/gmr15048708
}

\begin{abstract}
Coronary artery disease (CAD) has a high mortality rate in several countries. Interleukin (IL)-18 has been previously correlated with atherosclerotic plaque rupture. In this case-control study, the relationship between $-607 \mathrm{~A} / \mathrm{C}$ and $-372 \mathrm{C} / \mathrm{G}$ promoter polymorphisms in $I L-18$ and risk of CAD development was investigated. A total of 326 CAD patients were consecutively recruited from the First Hospital of Yulin between March 2013 and May 2015. The $I L-18-607 \mathrm{~A} / \mathrm{C}$ and $-372 \mathrm{C} / \mathrm{G}$ polymorphisms were genotyped by polymerase chain reactionrestriction fragment length polymorphism. Patients with CAD had a higher body mass index, a history of hypertension or diabetes (all $\mathrm{P}<$ $0.001)$, cigarette smoking habit $(\mathrm{P}=0.002)$; as well as higher plasma total cholesterol, triglyceride, and low-density lipoprotein cholesterol
\end{abstract}


levels (all $\mathrm{P}<0.001)$ and lower high-density lipoprotein cholesterol $(\mathrm{P}<0.001)$ levels compared to the control subjects. Unconditional logistic regression analysis revealed significant correlation between the CC genotype of $I L-18-607 \mathrm{~A} / \mathrm{C}$ and CAD development, compared to the AA genotype [adjusted odds ratio $(\mathrm{OR})=2.42 ; 95 \%$ confidence interval $(\mathrm{CI})=1.52-3.89 ; \mathrm{P}<0.001]$. The recessive model showed a significant association between the CC genotype of $I L-18-607 \mathrm{~A} / \mathrm{C}$ and an increased risk of $\mathrm{CAD}$, compared to the $\mathrm{AA}+\mathrm{AC}$ genotype $(\mathrm{OR}=$ $2.51,95 \% \mathrm{CI}=1.65-3.85)$. However, $I L-18-372 \mathrm{C} / \mathrm{G}$ did not contribute to the risk of glioma development in the co-dominant, dominant, and recessive models. Therefore, the $I L-18-607 \mathrm{C} / \mathrm{A}$ polymorphism was significantly correlated with the risk of CAD development.

Key words: IL-18; -607A/C; -372C/G; Polymorphism; Coronary artery disease

\section{INTRODUCTION}

Coronary artery disease (CAD) is commonly associated with a high mortality rate in most countries; more than $80 \%$ of the CAD cases have been reported in low- to median-income countries (He et al., 2005). CAD develops as a result of vascular tract stenosis or occlusion caused by coronary atherosclerotic lesions and several environmental and lifestyle factors (Campbell et al., 1998; Erbel and Görge, 2014; Bullock-Palmer, 2015). Previous experimental studies at the molecular level have indicated that many genetic factors, including the genes encoding angiotensinogen and angiotensin-converting enzyme, hepatic lipase, insulin receptor substrate-1, kinesin family member 6 , cholesteryl ester transfer protein, ATP-binding cassette subfamily A member 1, and apoptotic extrinsic death receptor, have an important role in the risk of CAD development (Bonfim-Silva et al., 2016; Cyrus et al., 2016; Kishore Kumar et al., 2016; Mohammadzadeh et al., 2016; Vatte et al., 2016; Zhang et al., 2016).

The inflammatory response could promote the formation and stability of plaques (Libby et al., 2002). Previous studies have indicated that several inflammatory factors contribute to the development of CAD, such as C-reactive protein, tumor necrosis factor, interleukin-6 (IL6), IL-17A, and transforming growth factor (Zernecke et al., 2008; Yang et al., 2015; Zheng et al., 2016). An association has also been reported between IL-18 and atherosclerotic plaque rupture (de Nooijer et al., 2004), which, in turn, is believed to influence the occurrence of CAD (Opstad et al., 2011). Polymorphisms in $I L-18$ are also believed to influence gene transcription, alter IL-18 expression, and promote development of cardiovascular diseases (Liu et al., 2013; Lu et al., 2013; Opstad et al., 2013; Hazzaa et al., 2014). Here, we performed a case-control study to investigate the relationship between the $-607 \mathrm{~A} / \mathrm{C}$ and $-372 \mathrm{C} / \mathrm{G}$ polymorphisms in the promoter region of $I L-18$ and risk of CAD development.

\section{MATERIAL AND METHODS}

\section{Patients}

A total of 326 patients with CAD were consecutively recruited from the First Hospital

Genetics and Molecular Research 15 (4): gmr15048708 
of Yulin between March 2013 and May 2015. CAD was newly diagnosed and confirmed by coronary angiography in all patients. CAD was characterized by a stenosis diameter of $50 \%$ in any of the major coronary arteries, such as the left main, left anterior descending, left circumflex, and right coronary arteries.

Control subjects were randomly selected from among individuals who visited the outpatient clinic of our hospital for a regular health check-up during the same time period. The controls were age- ( \pm 5 years) and gender-matched with the CAD patients. All control subjects were confirmed to be free of CAD or other cardiovascular diseases, chronic or acute infectious diseases, or malignant tumors.

The demographic, environmental, and clinical characteristics of the recruited patients and controls were obtained from medical records. The demographic and environmental factors included the gender, age, body mass index (BMI), history of hypertension and diabetes, habit of cigarette smoking and alcohol consumption levels, and so on. The clinical variables included the total cholesterol (TC), triglyceride (TG), low-density lipoprotein cholesterol (LDL-C), and high-density lipoprotein cholesterol (HDL-C) levels. Signed informed consent forms were obtained from all participants. This study was approved by the Ethics Committee of the First Hospital of Yulin.

\section{Genotyping}

Blood samples were collected from the cases and controls in EDTA-coated tubes. Total genomic DNA was extracted from these samples, using the Tiangen ${ }^{\circledR}$ DNA Blood Min kit (Tiangen Biotech Co., Ltd., Beijing, China). The IL-18 -607A/C and $-372 \mathrm{C} / \mathrm{G}$ polymorphic sites were genotyped by polymerase chain reaction (PCR)restriction fragment length polymorphism. The forward and reverse primers for $I L$ $18-607 \mathrm{~A} / \mathrm{C}$ and $-372 \mathrm{C} / \mathrm{G}$ were 5'-GTTGCAGAAAGTGAAAAATTATTAC-3' and 5'-GTTGCAGAAAGTGTAAAAATTATTAA-3' and 5'-CCCCAACTTTTACGGAAGAAAA G-3' and 5'-CCCCAACTTTTACGGAAGAAAAC-3', respectively. The $I L-18$-607A/C and $-372 \mathrm{C} / \mathrm{G}$ polymorphic sites were digested with $\mathrm{MseI}$ and $\mathrm{BfuCI}$, respectively. The PCR conditions were set as follows: initial denaturation at $94^{\circ} \mathrm{C}$ for $5 \mathrm{~min}, 30$ cycles of denaturation at $94^{\circ} \mathrm{C}$ for $45 \mathrm{~s}$, annealing at variable temperatures for $30 \mathrm{~s}$, and extension at $72^{\circ} \mathrm{C}$ for $45 \mathrm{~s}$. The amplification was verified on a $1.5 \%$ agarose gel.

\section{Statistical analysis}

Statistical variations between the demographic and clinical variables of the two study groups were determined using the chi-square $\left(\chi^{2}\right)$ test for categorical data and the Student $t$-test for continuous variables. Probable deviations of the $I L-18-607 \mathrm{~A} / \mathrm{C}$ and $-372 \mathrm{C} / \mathrm{G}$ polymorphisms from the Hardy-Weinberg equilibrium (HWE) were determined using the chi-square test, where the observed values were compared with the expected values. The correlation between $I L-18-607 \mathrm{~A} / \mathrm{C}$ and $-372 \mathrm{C} / \mathrm{G}$ polymorphisms and risk of CAD was analyzed by multivariate logistic regression analysis, and the results are reported as odds ratios (ORs) with their corresponding 95\% confidence intervals (CI). Interactions between the $I L-18$ $-607 \mathrm{~A} / \mathrm{C}$ and $-372 \mathrm{C} / \mathrm{G}$ polymorphisms and the potential risk factors of CAD were analyzed by the Spearman correlation analysis. Data analysis was performed using SPSS v.17.0 (SPSS Inc., Chicago, IL, USA).

Genetics and Molecular Research 15 (4): gmr15048708 


\section{RESULTS}

As expected, the CAD patients and controls are comparable in terms of age $\left(\chi^{2}=\right.$ $0.09, \mathrm{P}=0.75)$ and gender $\left(\chi^{2}<0.001, \mathrm{P}=1.00\right)$ (Table 1$)$. The chi-square and Student $t$-tests showed no significant differences in the alcohol consumption levels $\left(\chi^{2}=1.16, \mathrm{P}=0.28\right)$ between the CAD patients and control subjects. The patients with CAD had higher BMI $\left(\chi^{2}\right.$ $=19.83, \mathrm{P}<0.001)$, higher probability of a history of hypertension $\left(\chi^{2}=52.49, \mathrm{P}<0.001\right)$ or diabetes $\left(\chi^{2}=8.65, \mathrm{P}=0.003\right)$, cigarette smoking habit $\left(\chi^{2}=9.29, \mathrm{P}=0.002\right)$, as well as higher plasma TC $(t=4.61, \mathrm{P}<0.001), \mathrm{TG}(t=4.70, \mathrm{P}<0.001)$, and LDL-C $(t=9.01, \mathrm{P}<$ $0.001)$ levels, and lower HDL-C $(t=12.31, \mathrm{P}<0.001)$ levels compared to the control subjects.

Table 1. Demographic, lifestyle, and clinical characteristics of patients with coronary artery disease (CAD) and control subjects included in this study.

\begin{tabular}{|c|c|c|c|c|c|c|}
\hline Variables & $\begin{array}{c}\text { Patients } \\
(\mathrm{N}=326)\end{array}$ & $\%$ & $\begin{array}{l}\text { Controls } \\
(\mathrm{N}=326)\end{array}$ & $\%$ & $\chi^{2}$ or $t$-value & P value \\
\hline \multicolumn{7}{|l|}{ Age (years) } \\
\hline$<60$ & 148 & 45.40 & 152 & 46.63 & & \\
\hline$\geq 60$ & 178 & 54.60 & 174 & 53.37 & 0.09 & 0.75 \\
\hline \multicolumn{7}{|l|}{ Gender } \\
\hline Male & 214 & 65.64 & 214 & 65.64 & & \\
\hline Female & 112 & 34.36 & 112 & 34.36 & $<0.001$ & 1.00 \\
\hline \multicolumn{7}{|l|}{ BMI $\left(\mathrm{kg} / \mathrm{m}^{2}\right)$} \\
\hline$<24$ & 187 & 57.36 & 241 & 73.93 & & \\
\hline$\geq 24$ & 139 & 42.64 & 85 & 26.07 & 19.83 & $<0.001$ \\
\hline \multicolumn{7}{|l|}{ Hypertension } \\
\hline No & 180 & 55.21 & 266 & 81.60 & & \\
\hline Yes & 146 & 44.79 & 60 & 18.40 & 52.49 & $<0.001$ \\
\hline \multicolumn{7}{|l|}{ Diabetes } \\
\hline No & 246 & 75.46 & 276 & 84.66 & & \\
\hline Yes & 80 & 24.54 & 50 & 15.34 & 8.65 & 0.003 \\
\hline \multicolumn{7}{|c|}{ Alcohol consumption } \\
\hline Never & 210 & 64.42 & 223 & 68.40 & & \\
\hline Yes & 116 & 35.58 & 103 & 31.60 & 1.16 & 0.28 \\
\hline \multicolumn{7}{|l|}{ Cigarette smoking } \\
\hline Never & 179 & 54.91 & 217 & 66.56 & & \\
\hline Yes & 147 & 45.09 & 109 & 33.44 & 9.29 & 0.002 \\
\hline $\mathrm{TC}(\mathrm{mM} / \mathrm{dL})$ & & $195.52 \pm 41.67$ & & $181.34 \pm 36.75$ & 4.61 & $<0.001$ \\
\hline TG $(\mathrm{mM} / \mathrm{dL})$ & & $135.34 \pm 39.52$ & & $121.53 \pm 35.40$ & 4.70 & $<0.001$ \\
\hline LDL-C (mM/dL) & & $121.50 \pm 34.20$ & & $98.64 \pm 30.55$ & 9.01 & $<0.001$ \\
\hline HDL-C $(\mathrm{mM} / \mathrm{dL})$ & & $36.72 \pm 8.63$ & & $45.60 \pm 9.76$ & 12.31 & $<0.001$ \\
\hline
\end{tabular}

BMI, body mass index; TC, total cholesterol; TG, triglyceride; LDL-C, low-density lipoprotein cholesterol; HDL-C, high-density lipoprotein cholesterol.

The AA, AC, and CC genotypes of $I L-18-607 \mathrm{~A} / \mathrm{C}$ were observed in $33.13 \%$ (108), $39.26 \%$ (128), and $27.61 \%$ (90) of all patients, and 38.34\% (125), 48.47\% (158), and $13.19 \%$ (43) of the control subjects, respectively. Alternately, the GG, GC, and CC genotypes of the $I L-18-372 \mathrm{G} / \mathrm{C}$ polymorphism were observed in $69.02 \%$ (225), $27.61 \%$ (90), and $3.37 \%$ (11) of all patients, and $73.01 \%$ (238), 24.54\% (80), and 2.45\% (8) controls, respectively (Table $2)$. The chi-square test revealed significant differences between genotype distributions of $I L-18-607 \mathrm{~A} / \mathrm{C}\left(\chi^{2}=21.00, \mathrm{P}<0.001\right)$ and no significant differences between the genotype distributions of $I L-18-372 \mathrm{C} / \mathrm{G}\left(\chi^{2}=1.43, \mathrm{P}=0.49\right)$. The genotype frequencies of $I L-18$ $-607 \mathrm{~A} / \mathrm{C}\left(\chi^{2}=0.40, \mathrm{P}=0.53\right)$ and $-372 \mathrm{C} / \mathrm{G}\left(\chi^{2}=0.17, \mathrm{P}=0.68\right)$ in the control subjects were in line with the HWE. 
Table 2. Genotype distributions of the interleukin $18(I L-18)-607 \mathrm{~A} / \mathrm{C}$ and $-372 \mathrm{C} / \mathrm{G}$ polymorphisms in the patients and controls.

\begin{tabular}{|c|c|c|c|c|c|c|c|c|}
\hline \multirow[t]{2}{*}{$I L-18$} & \multirow{2}{*}{$\begin{array}{c}\text { Patients } \\
(\mathrm{N}=326)\end{array}$} & \multirow[t]{2}{*}{$\%$} & \multirow{2}{*}{$\begin{array}{c}\text { Controls } \\
(\mathrm{N}=326)\end{array}$} & \multirow[t]{2}{*}{$\%$} & \multirow[t]{2}{*}{$\chi^{2}$} & \multirow[t]{2}{*}{$P$ value } & \multicolumn{2}{|c|}{ HWE in controls } \\
\hline & & & & & & & Chi-square & $P$ value \\
\hline \multicolumn{9}{|c|}{$-607 \mathrm{~A} / \mathrm{C}$} \\
\hline AA & 108 & 33.13 & 125 & 38.34 & & & & \\
\hline $\mathrm{AC}$ & 128 & 39.26 & 158 & 48.47 & & & & \\
\hline $\mathrm{CC}$ & 90 & 27.61 & 43 & 13.19 & 21.00 & $<0.001$ & 0.40 & 0.53 \\
\hline \multicolumn{9}{|c|}{$-372 \mathrm{G} / \mathrm{C}$} \\
\hline GG & 225 & 69.02 & 238 & 73.01 & & & & \\
\hline $\mathrm{GC}$ & 90 & 27.61 & 80 & 24.54 & & & & \\
\hline $\mathrm{CC}$ & 11 & 3.37 & 8 & 2.45 & 1.43 & 0.49 & 0.17 & 0.68 \\
\hline
\end{tabular}

HWE, Hardy-Weinberg equilibrium.

Unconditional logistic regression analysis revealed a significant correlation between the CC genotype of $I L-18-607 \mathrm{~A} / \mathrm{C}$ and CAD development, compared to the AA genotype (adjusted $\mathrm{OR}=2.42 ; 95 \% \mathrm{CI}=1.52-3.89 ; \mathrm{P}<0.001$ ) (Table 3). Alternately, the recessive model showed a significant correlation between the CC genotype of $I L-18-607 \mathrm{~A} / \mathrm{C}$ and an increased risk of $\mathrm{CAD}$, compared to the $\mathrm{AA}+\mathrm{AC}$ genotype $(\mathrm{OR}=2.51,95 \% \mathrm{CI}=1.65-3.85)$. However, the $I L-18-372 \mathrm{C} / \mathrm{G}$ did not contribute to the risk of glioma development.

\begin{tabular}{|c|c|c|c|c|c|c|}
\hline \multirow[t]{2}{*}{$I L-18$} & \multirow{2}{*}{$\begin{array}{c}\text { Patients } \\
(\mathrm{N}=326)\end{array}$} & \multirow[t]{2}{*}{$\%$} & \multirow{2}{*}{$\begin{array}{c}\text { Controls } \\
(\mathrm{N}=326)\end{array}$} & \multirow[t]{2}{*}{$\%$} & \multicolumn{2}{|c|}{ Multivariate logistic regression analysis } \\
\hline & & & & & Adjusted OR $(95 \% \mathrm{Cl})^{1}$ & P value \\
\hline \multicolumn{7}{|c|}{$-607 \mathrm{~A} / \mathrm{C}$} \\
\hline \multicolumn{7}{|c|}{ Co-dominant model } \\
\hline AA & 108 & 33.13 & 125 & 38.34 & 1.0 (Ref.) & - \\
\hline $\mathrm{AC}$ & 128 & 39.26 & 158 & 48.47 & $0.94(0.65-1.35)$ & 0.72 \\
\hline $\mathrm{CC}$ & 90 & 27.61 & 43 & 13.19 & $2.42(1.52-3.89)$ & $<0.001$ \\
\hline \multicolumn{7}{|c|}{ Dominant model } \\
\hline AA & 108 & 33.13 & 125 & 38.34 & 1.0 (Ref.) & - \\
\hline $\mathrm{AC}+\mathrm{CC}$ & 218 & 66.87 & 201 & 61.66 & $1.26(0.90-1.75)$ & 0.16 \\
\hline \multicolumn{7}{|c|}{ Recessive model } \\
\hline $\mathrm{AA}+\mathrm{AC}$ & 236 & 72.39 & 283 & 86.81 & 1.0 (Ref.) & - \\
\hline $\mathrm{CC}$ & 90 & 27.61 & 43 & 13.19 & $2.51(1.65-3.85)$ & $<0.001$ \\
\hline \multicolumn{7}{|c|}{$-372 \mathrm{G} / \mathrm{C}$} \\
\hline \multicolumn{7}{|c|}{ Co-dominant model } \\
\hline GG & 225 & 69.02 & 238 & 73.01 & 1.0 (Ref.) & - \\
\hline $\mathrm{GC}$ & 90 & 27.61 & 80 & 24.54 & $1.19(0.82-1.72)$ & 0.33 \\
\hline $\mathrm{CC}$ & 11 & 3.37 & 8 & 2.45 & $1.45(0.52-4.24)$ & 0.43 \\
\hline \multicolumn{7}{|c|}{ Dominant model } \\
\hline GG & 225 & 69.02 & 238 & 73.01 & 1.0 (Ref.) & - \\
\hline $\mathrm{GC}+\mathrm{CC}$ & 101 & 30.98 & 88 & 26.99 & $1.21(0.85-1.73)$ & 0.26 \\
\hline \multicolumn{7}{|c|}{ Recessive model } \\
\hline $\mathrm{GG}+\mathrm{GC}$ & 315 & 96.63 & 318 & 97.55 & 1.0 (Ref.) & - \\
\hline $\mathrm{CC}$ & 11 & 3.37 & 8 & 2.45 & $1.39(0.50-4.03)$ & 0.48 \\
\hline
\end{tabular}

${ }^{1}$ Adjusted for body mass index, hypertension, diabetes, cigarette smoking, total cholesterol, triglyceride, lowdensity lipoprotein cholesterol, and high-density lipoprotein cholesterol. OR, odds ratio; CI, confidence interval.

Spearman correlation analysis revealed no significant correlation between the $I L$ $18-607 \mathrm{~A} / \mathrm{C}$ and $-372 \mathrm{C} / \mathrm{G}$ polymorphisms and BMI, hypertension, diabetes, and cigarette smoking habit, and the TC, TG, LDL-C, and HDL-C levels in CAD risk (P values for all correlations $>0.05$ ). 


\section{DISCUSSION}

The $I L-18-607 \mathrm{C} / \mathrm{A}$ and $-137 \mathrm{G} / \mathrm{C}$ polymorphisms are located at the junction of the response elements of nuclear factor cAMP binding protein. Previous studies have indicated that the $I L-18-607 \mathrm{C} / \mathrm{A}$ and $-137 \mathrm{G} / \mathrm{C}$ polymorphisms influence the expression of IL-18 and IFN- $\gamma$; moreover, the expression of $I L-18-607 \mathrm{CC}$ and $-137 \mathrm{GG}$ genotypes were significantly higher those of other genotypes (Giedraitis et al., 2001). IL-18 expression is also positively correlated with the expression of $I L-18$ mRNA (Giedraitis et al., 2001). Additionally, the A and C alleles of $I L-18-607 \mathrm{C} / \mathrm{A}$ and $-137 \mathrm{G} / \mathrm{C}$ are believed to induce low IL-18 activity (Giedraitis et al., 2001; Liang et al., 2005; Arimitsu et al., 2006). Some studies have also indicated that patients with cardiovascular and cerebrovascular diseases have significantly higher levels of IL-18 in the plasma compared to the healthy controls, which was associated with disease development (Chen et al., 2007; Gao et al., 2010; Liu et al., 2013; Li et al., 2014). Here, we attempted to elucidate the association between the $I L-18-607 \mathrm{C} / \mathrm{A}$ and $-137 \mathrm{G} / \mathrm{C}$ polymorphisms and risk of $\mathrm{CAD}$; we determined that the $\mathrm{CC}$ genotype of $I L-18-607 \mathrm{~A} / \mathrm{C}$ could elevate the risk of CAD, compared to the wild-type genotype.

Previous studies have indicated a close association between functional $I L-18$ polymorphisms and the risk of developing cardiovascular and cerebrovascular diseases (Thompson et al., 2007; Liu et al., 2009; Pei et al., 2009; Hernesniemi et al., 2010a,b; Zhang et al., 2010; Lu et al., 2013). Liu et al. (2009), in a study conducted in 241 Chinese patients with CAD and 145 control subjects, reported that the $I L-18-137 \mathrm{G} / \mathrm{C}$ polymorphism influenced IL-18 expression and the occurrence of CAD. Pei et al. (2009) and Lu et al. (2013) reported that the $I L-18-607 \mathrm{C} / \mathrm{A}$ polymorphism influenced the risk of acute myocardial infarction or ischemic stroke in a northern Chinese Han population. However, other studies did not find any significant association between $I L-18$ polymorphisms and coronary heart disease and atherosclerosis (Thompson et al., 2007; Hernesniemi et al., 2010a,b). The discrepancies among these studies could be attributed to differences in the diseases investigated, study populations, study design, and sample size.

Three major limitations should be paid attention. Firstly, patients and controls were selected from only one hospital, which could induce selection bias in our study. Secondly, polymorphisms in genes other than $I L-18(-607 \mathrm{C} / \mathrm{A}$ and $-137 \mathrm{G} / \mathrm{C})$ may influence the development of this disease, and interact with $I L-18$.

In summary, we observed a statistically significant relationship between the $I L-18$ $-607 \mathrm{C} / \mathrm{A}$ polymorphism and risk of developing coronary artery disease; however, the $I L-18$ $-137 \mathrm{G} / \mathrm{C}$ polymorphism was not correlated with this disease. Our results should be confirmed by further studies.

\section{Conflicts of interest}

The authors declare no conflict of interest.

\section{ACKNOWLEDGMENTS}

We thank the nurses from the First Hospital of Yulin for helping us to collect the blood samples.

Genetics and Molecular Research 15 (4): gmr15048708 


\section{REFERENCES}

Arimitsu J, Hirano T, Higa S, Kawai M, et al. (2006). IL-18 gene polymorphisms affect IL-18 production capability by monocytes. Biochem. Biophys. Res. Commun. 342: 1413-1416.http://dx.doi.org/10.1016/j.bbrc.2006.02.096

Bonfim-Silva R, Guimarães LO, Souza Santos J, Pereira JF, et al. (2016). Case-control association study of polymorphisms in the angiotensinogen and angiotensin-converting enzyme genes and coronary artery disease and systemic artery hypertension in African-Brazilians and Caucasian-Brazilians. J. Genet. 95: 63-69.http://dx.doi.org/10.1007/s12041$\underline{015-0599-5}$

Bullock-Palmer RP (2015). Prevention, detection and management of coronary artery disease in minority females. Ethn. Dis. 25: 499-506. http://dx.doi.org/10.18865/ed.25.4.499

Campbell TC, Parpia B and Chen J (1998). Diet, lifestyle, and the etiology of coronary artery disease: the Cornell China study. Am. J. Cardiol. 82 (10B): 18T-21T. http://dx.doi.org/10.1016/S0002-9149(98)00718-8

Chen MC, Chen CJ, Yang CH, Wu CJ, et al. (2007). Interleukin-18: a strong predictor of the extent of coronary artery disease in patients with unstable angina. Heart Vessels 22: 371-375. http://dx.doi.org/10.1007/s00380-007-0991-z

Cyrus C, Vatte C, Al-Nafie A, Chathoth S, et al. (2016). The impact of common polymorphisms in CETP and ABCA1 genes with the risk of coronary artery disease in Saudi Arabians. Hum. Genomics 10: 8. http://dx.doi.org/10.1186/ s40246-016-0065-3

de Nooijer R, von der Thüsen JH, Verkleij CJ, Kuiper J, et al. (2004). Overexpression of IL-18 decreases intimal collagen content and promotes a vulnerable plaque phenotype in apolipoprotein-E-deficient mice. Arterioscler. Thromb. Vasc. Biol. 24: 2313-2319. http://dx.doi.org/10.1161/01.ATV.0000147126.99529.0a

Erbel R and Görge G (2014). New insights in pathogenesis and etiology of coronary artery disease. Dtsch. Med. Wochenschr. 139 (Suppl 1): S4-S8.

Gao Y, Tong GX, Zhang XW, Leng JH, et al. (2010). Interleukin-18 levels on admission are associated with mid-term adverse clinical events in patients with ST-segment elevation acute myocardial infarction undergoing percutaneous coronary intervention. Int. Heart J. 51: 75-81. http://dx.doi.org/10.1536/ihj.51.75

Giedraitis V, He B, Huang WX and Hillert J (2001). Cloning and mutation analysis of the human IL-18 promoter: a possible role of polymorphisms in expression regulation. J. Neuroimmunol. 112: 146-152. http://dx.doi.org/10.1016/ $\underline{\mathrm{S} 0165-5728(00) 00407-0}$

Hazzaa HH, Rashwan WA and Attia EA (2014). IL-18 gene polymorphisms in aphthous stomatitis vs. Behçet's disease in a cohort of Egyptian patients. J. Oral Pathol. Med. 43: 746-753.http://dx.doi.org/10.1111/jop.12200

He J, Gu D, Wu X, Reynolds K, et al. (2005). Major causes of death among men and women in China. N. Engl. J. Med. 353: 1124-1134. http://dx.doi.org/10.1056/NEJMsa050467

Hernesniemi JA, Heikkilä A, Raitakari OT, Kähönen M, et al. (2010a). Interleukin-18 gene polymorphism and markers of subclinical atherosclerosis. The Cardiovascular Risk in Young Finns Study. Ann. Med. 42: 223-230. http://dx.doi. org $10.3109 / 07853891003769940$

Hernesniemi JA, Anttila K, Nieminen T, Kähönen M, et al. (2010b). IL-18 gene polymorphism, cardiovascular mortality and coronary artery disease. Eur. J. Clin. Invest. 40: 994-1001.http://dx.doi.org/10.1111/j.1365-2362.2010.02356.x

Kishore Kumar G, Rajesh Kumar G, Mrudula Spurthi K, Nivas S, et al. (2016). Polymorphisms of extrinsic death receptor apoptotic genes (FAS -670 G>A, FASL -844 T>C) in coronary artery disease. Apoptosis 21: 558-565. http://dx.doi. org/10.1007/s10495-016-1232-7

Li Q, Li Z, Zhang X, Ruan Y, et al. (2014). Evaluated plasma interleukin-18/interleukin-10 ratio is a risk factor for acute coronary syndromes in patients with stable angina pectoris. Cardiol. J. 21: 83-88. http://dx.doi.org/10.5603/ CJ.a2013.0057

Liang XH, Cheung W, Heng CK and Wang DY (2005). Reduced transcriptional activity in individuals with IL-18 gene variants detected from functional but not association study. Biochem. Biophys. Res. Commun. 338: 736-741. http:// dx.doi.org/10.1016/j.bbrc.2005.10.012

Libby P, Ridker PM and Maseri A (2002). Inflammation and atherosclerosis. Circulation 105: 1135-1143. http://dx.doi. org $/ 10.1161 / \mathrm{hc} 0902.104353$

Liu W, Tang Q, Jiang H, Ding X, et al. (2009). Promoter polymorphism of interleukin-18 in angiographically proven coronary artery disease. Angiology 60: 180-185.

Liu W, Liu Y, Jiang H, Ding X, et al. (2013). Plasma levels of interleukin 18, interleukin 10, and matrix metalloproteinase-9 and $-137 \mathrm{G} / \mathrm{C}$ polymorphism of interleukin 18 are associated with incidence of in-stent restenosis after percutaneous coronary intervention. Inflammation 36: 1129-1135. http://dx.doi.org/10.1007/s10753-013-9647-6

Lu JX, Lu ZQ, Zhang SL, Zhi J, et al. (2013). Correlation between interleukin-18 promoter -607C/A polymorphism and susceptibility to ischemic stroke. Braz. J. Med. Biol. Res. 46: 502-506.http://dx.doi.org/10.1590/1414-431X20132850

Genetics and Molecular Research 15 (4): gmr15048708 
Mohammadzadeh G, Ghaffari MA, Bazyar M and Kheirollah A (2016). Association between two common polymorphisms (single nucleotide polymorphism $-250 \mathrm{G} / \mathrm{A}$ and $-514 \mathrm{C} / \mathrm{T}$ ) of the hepatic lipase gene and coronary artery disease in type 2 diabetic patients. Adv. Biomed. Res. 5: 27. http://dx.doi.org/10.4103/2277-9175.176366

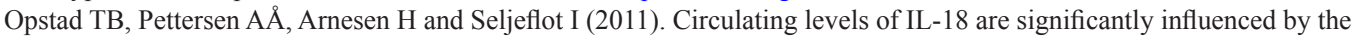
IL-18 $+183 \mathrm{~A} / \mathrm{G}$ polymorphism in coronary artery disease patients with diabetes type 2 and the metabolic syndrome: an observational study. Cardiovasc. Diabetol. 10: 110. http://dx.doi.org/10.1186/1475-2840-10-110

Opstad TB, Pettersen AÅ, Arnesen H and Seljeflot I (2013). The co-existence of the IL-18+183 A/G and MMP-9 -1562 $\mathrm{C} / \mathrm{T}$ polymorphisms is associated with clinical events in coronary artery disease patients. PLoS One 8: e74498. http:// dx.doi.org/10.1371/journal.pone.0074498

Pei F, Han Y, Zhang X, Yan C, et al. (2009). Association of interleukin-18 gene promoter polymorphisms with risk of acute myocardial infarction in northern Chinese Han population. Clin. Chem. Lab. Med. 47: 523-529. http://dx.doi. org/10.1515/CCLM.2009.130

Thompson SR, Sanders J, Stephens JW, Miller GJ, et al. (2007). A common interleukin 18 haplotype is associated with higher body mass index in subjects with diabetes and coronary heart disease. Metabolism 56: 662-669. http://dx.doi. org/10.1016/j.metabol.2006.12.015

Vatte C, Cyrus C, AlShehri AM, Chathoth S, et al. (2016). Investigation of KIF6 Trp719Arg gene polymorphism in a casecontrol study of coronary artery disease and non-fatal myocardial infarction in the Eastern Province of Saudi Arabia. Ann. Saudi Med. 36: 105-111.

Yang HT, Wang SL, Yan LJ, Qian P, et al. (2015). Association of interleukin gene polymorphisms with the risk of coronary artery disease. Genet. Mol. Res. 14: 12489-12496. http://dx.doi.org/10.4238/2015.October.16.16

Zernecke A, Shagdarsuren E and Weber C (2008). Chemokines in atherosclerosis: an update. Arterioscler. Thromb. Vasc. Biol. 28: 1897-1908.http://dx.doi.org/10.1161/ATVBAHA.107.161174

Zhang D, Zhang X, Liu D, Liu T, et al. (2016). Association between insulin receptor substrate-1 polymorphisms and high platelet reactivity with clopidogrel therapy in coronary artery disease patients with type 2 diabetes mellitus. Cardiovasc. Diabetol. 15: 50. http://dx.doi.org/10.1186/s12933-016-0362-0

Zhang N, Yu JT, Yu NN, Lu RC, et al. (2010). Interleukin-18 promoter polymorphisms and risk of ischemic stroke. Brain Res. Bull. 81: 590-594.http://dx.doi.org/10.1016/j.brainresbull.2010.01.008

Zheng XS, Wang S and Ni M (2016). Association between interleukin 17A gene polymorphisms and risk of coronary artery disease. Genet. Mol. Res.: 15 [doi: 10.4238/gmr.15017074].http://dx.doi.org/10.4238/gmr.15017074

Genetics and Molecular Research 15 (4): gmr15048708 